\title{
After Hultsfred: Cultural Entrepreneurship in the Aftermath of the Hultsfred Festival
}

\author{
Jonas Bjälesjö \\ Linnaeus University School of Business \& Economics \\ This paper was presented at the 2018 International Summit of the \\ Music \& Entertainment Industry Educators Association \\ March 22-24, 2018
}

\section{https://doi.org/10.25101/18.33}

\section{Abstract}

This paper will present some of the results and the outline for two articles that will be included in the research project's final product: an anthology scheduled for release at the turn of the year 2018. The research project (started in January 2015) has had its focus on cultural entrepreneurship in relation and as a result of a popular music festival that took place in the southeast part of Sweden from 1986 to 2009. The project is funded by the Kamprad Family Foundation.

In the autumn of 1981, a group of music-loving young people met in Hultsfred, a small municipal community of about 5,000 inhabitants, situated in the northeastern part of the county of Småland, Sweden. Fed up with the fact that nothing seemed to happen, they put up posters and on December 16, 1981 a large group met at the local community youth center and founded the rock association, Rockparty. In 1986 Rockparty launched the Hultsfred festival that would become the largest and most important popular music festival in Sweden during the late 1980s and the 1990s. The association developed from being a small voluntary-based rock association to becoming Sweden's largest festival promoter creating a lot of cultural activities and creativity, businesses, concerts, festivals, education, research, etc., especially in the project Rockcity, launched in the year 2000. My doctoral thesis "Rock'n'roll i Hultsfred - ungdomar, festival och lokal gemenskap" examined how this development was possible. This research project is to some degree an extension of my doctoral thesis.

One issue I have investigated is how people and their cultural entrepreneurship seems to be founded on different aspects of friendship and the creation and maintenance/support or loss/lack of social capital. How did friendship and social capital work together to create the social networks crucial for the cultural activities mentioned above? Another issue I have investigated is what kind of skills they learned and developed through the cultural practices they were involved in. With today's viewpoint the persons learning pro- cesses have been researched and analyzed. I have tried to reconstruct the learning trajectories. That is, the birth, journey and meaning of their activities and learning processes connected to these activities. How have these cultural entrepreneurs understood and used those driving forces of meaning, learning processes, knowledge and experience, their friendship and social networks (social capital)?

Keywords: Hultsfred Festival, cultural entrepreneurship, Rockparty, Rockcity, youth culture, music festivals

Jonas Bjälesjö, $\mathrm{PhD}$, is subject teacher at the Music \& Event Management Program, Linnaeus University School of Business \& Economics, Kalmar \& Hultsfred, Sweden. He teaches the subjects Music \& Event Management with focus on cultural and social aspects of music and music industry. His research is focused around popular music, youth culture, music festivals, local music life and music tourism with focus on the festival phenomena and the landscape of Scandinavian music festivals. His doctoral thesis Rock'n'roll $i$ Hultsfred - ungdomar, festival och lokal gemenskap was published in 2013. He is also on the board of the Swedish Rockarchives.

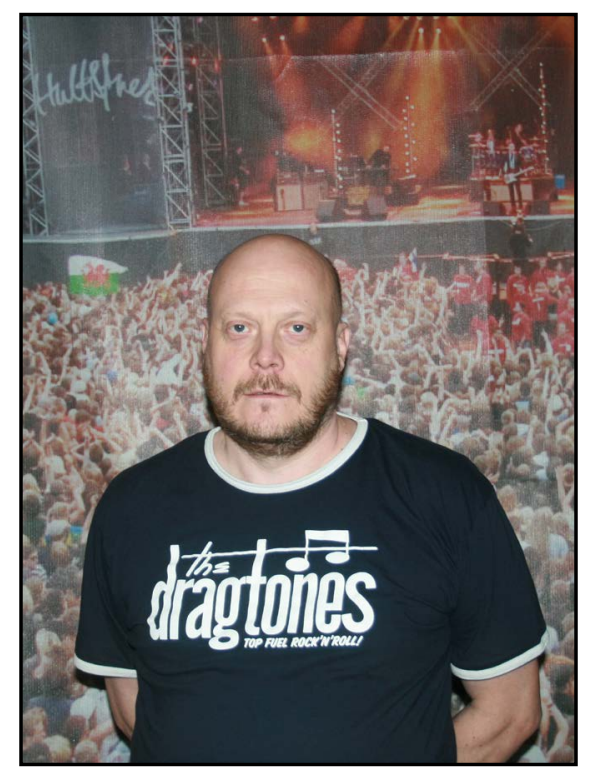




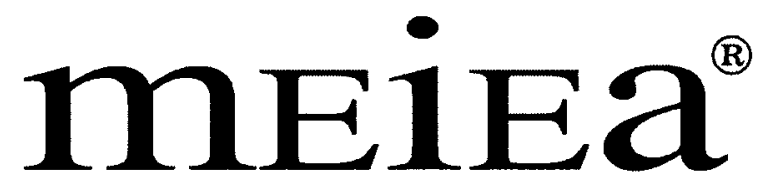

MUSIC \& ENTERTAINMENT INDUSTRY

EDUCATORS ASSOCIATION

\section{PROCEEDINGS OF THE \\ 2018 INTERNATIONAL SUMMIT}

OF THE

\section{MUSIC \& ENTERTAINMENT INDUSTRY EDUCATORS \\ ASSOCIATION}
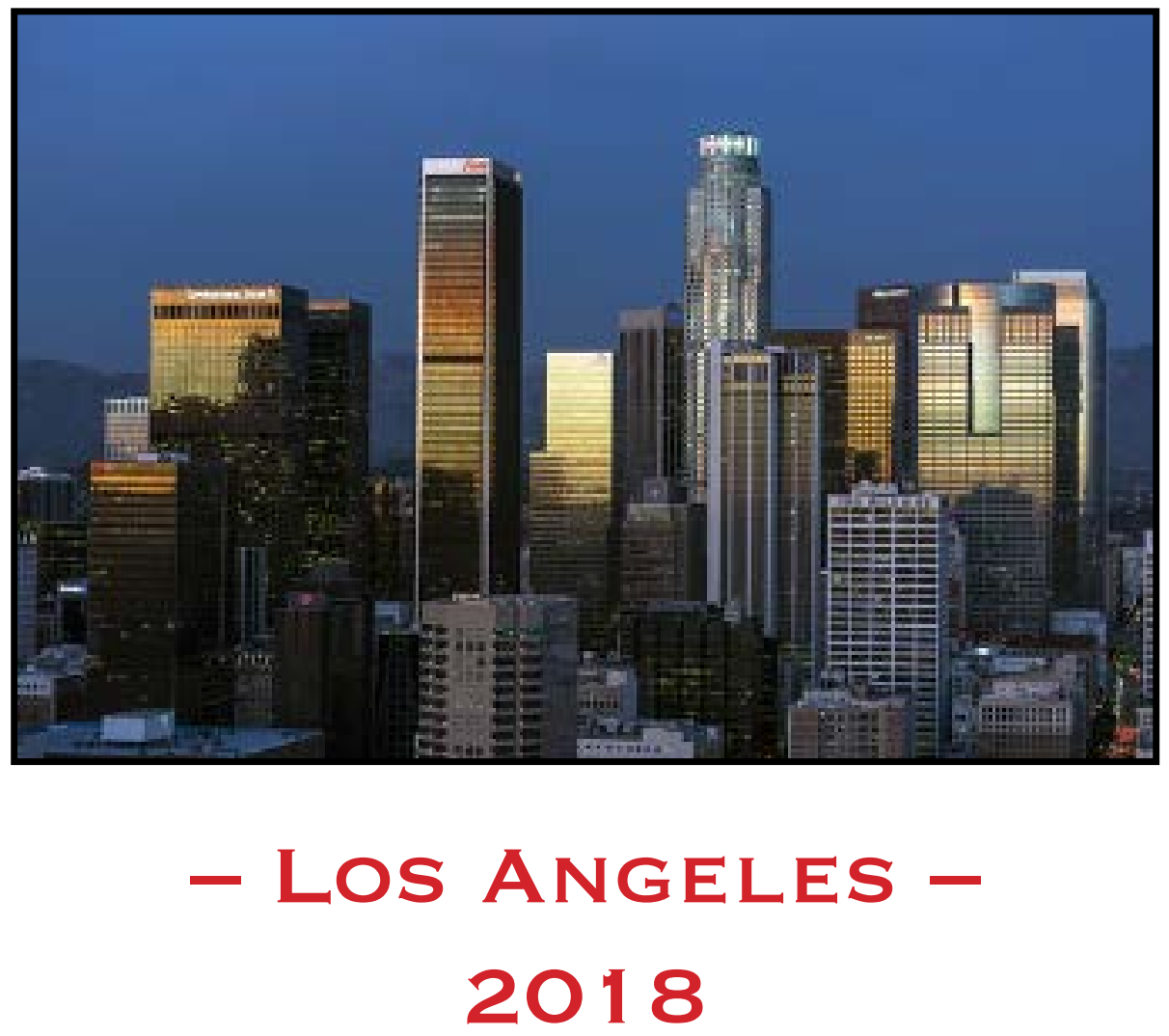

March 22 - 24, $2018 \cdot$ Embassy Suites by Hilton - Los Angeles/Glendale 